\title{
Situation analysis of energy use and consumption in Cambodia: household access to energy
}

\author{
Korkeakoski Mika ${ }^{1}$ (D) Mentula Minna ${ }^{1}$ - Vähäkari Noora ${ }^{1} \cdot$ Luukkanen Jyrki $^{1}$. \\ Kaivo-oja Jari ${ }^{1} \cdot$ Alexeeva Anna ${ }^{1}$. Chea Eliyan ${ }^{2} \cdot$ Va Dany $^{2} \cdot$ Kallio Maarit $^{3,4}$. \\ Hogarth Nicholas ${ }^{3,4}$
}

Received: 21 September 2020 / Accepted: 14 April 2021 / Published online: 26 April 2021

(C) The Author(s) 2021

\begin{abstract}
The aim of this article is to analyse the current situation of access to energy (in relation to SDG 7) and energy usage behaviour in households in two provinces in Cambodia, namely Pursat and Kampong Cham. The analytical framework is based on the energy ladder model and the energy stacking model as a starting point for assessing the current household energy profiles. A quantitative survey carried out in late 2015 in 970 households revealed differences in access to electricity between urban, electrified rural, and non-electrified rural districts. In urban areas, households are using multiple (3-4) energy sources compared to rural areas (2-3). The use of electricity through batteries in the non-electrified rural areas remains notable (43\%) despite no access to the national grid. The dependence on traditional biomass, especially firewood, remains high (91\% of all respondents) for all the sampled households, especially so in rural non-electrified households. The study confirms that households' energy mix is composed of various energy sources, even when modern energy sources are available as opposed to complete fuel switch. The results also show that electricity use does not automatically lead to increased household income, but is much more complex process than discussed in existing research. The article further discusses the possible causes behind the phenomenon, proposes recommendations for better-informed energy policy, and provides important insights towards sustainable energy transition in Cambodia in the future.
\end{abstract}

Keywords Energy consumption · Households · Cambodia $\cdot$ Energy transition · Energy use models $\cdot$ Development pathways

Korkeakoski Mika

mika.korkeakoski@utu.fi

1 Finland Futures Research Centre, Turku School of Economics, University of Turku, Korkeavuorenkatu 25 A 2, 00130 Helsinki, Finland

2 Department of Environmental Science, Royal University of Phnom Penh Russian Federation Boulevard, Toul Kork, Phnom Penh, Cambodia

3 Faculty of Agriculture and Forestry, Viikki Tropical Resources Institute (VITRI), University of Helsinki, Latokartanonkaari 7, 00014 Helsinki, Finland

4 Helsinki Institute of Sustainability Science (HELSUS), University of Helsinki, Yliopistonkatu 3, 00014 Helsinki, Finland 


\section{Introduction}

According to the International Energy Agency (IEA), there were 770 million people without access to electricity in the world in 2019; a decrease from 1.7 billion people in 2000 (IEA, 2019). The accelerating progression of this trend has happened mostly via the expansion of electricity grids and the use of fossil fuels (IEA 2017). However, electricity generation is still heavily dependent on fossil fuels, nuclear, or large-scale hydropower, which makes the sustainability aspects of the energy sector development problematic. In many cases, the reliance on government-subsidized imported fossil fuels can become an economic burden, especially given international market price fluctuations (Bhattacharyya, 2012). Furthermore, fossil fuel-based electricity production is a major global, regional, and local polluter and emission source, accounting for over $40 \%$ of global GHG emissions (IEA, 2018). The increase in global energy demand is most clearly driven by industrialization and increased access to energy in developing countries, with China and India contributing to most of the increase (IEA 2015). On the other hand, countries in the Global South now have an opportunity to leapfrog the industrial and polluting phase by'greening' their technology, infrastructure, and practices. As the industrialized history in many countries in the south is shorter, it could be possible to challenge the path dependency of fossil-based societies.

The United Nations Agenda 2030 highlights access to energy in its Sustainable Development Goal (SDG) 7, which aims for "affordable, reliable, sustainable and modern energy for all by the year 2030" (UN 2015). SDG 7 is considered as a medium goal, contributing to the achievement of other goals. According to Bhattacharyya (2012), access to both electricity and cooking energy have strong correlations with Gross National Income (GNI), but the correlation is even stronger with the Human Development Index (HDI). In addition to GNI, HDI contains data from life expectancy at birth and mean schooling years; indicating that access to energy has an influence on economic growth, but its influence is even stronger on the wellbeing of people (Phoumin \& Kimura, 2019). However, rural economic development and income generation are not always strongly linked with electrification, as electricity is mostly used for lighting and televisions (Bhattacharyya, 2012). In addition, unreliable and costly grid electricity may hinder starting up and maintaining businesses in developing countries, especially in rural areas (ADB 2018; Phoumin et al., 2020).

Cambodia has been on the United Nations list of the least developed countries since 1991. In 2015 Cambodia's Human Development Index (HDI) was 0.563, which is below the medium HDI of 0.631 and below the East Asia and Pacific average of 0.720 (UNDP 2016). Coupled with a high rate of poverty (18.76\% in 2014; Royal Government of Cambodia, 2015), Cambodia is still under the LDC graduation threshold according to UN triennial statistics in 2018 (UN 2018). Most of its land area is classified as rural, approximately 99\% in 2010 (World Bank 2017).

In Cambodia, large-scale hydropower has dominated national power development plans. Although categorized as renewable, large-scale hydropower has, however, been criticized for its impacts on the environment and societies (e.g. Siciliano et al. 2015). In most cases, hydropower plants have greenhouse gas emissions comparable to other renewable energy sources, but Räsänen et al. (2018) found that $18 \%$ of hydropower reservoirs, and $55 \%$ of reservoirs with irrigation in the Mekong River Basin, have far greater emissions. Furthermore, fourteen of the examined reservoir emissions were even comparable to emissions of fossil fuel plants (Räsänen et al. 2018). The increasing discussion around transitions towards a Green Economy in Cambodia, a term widely supported by, e.g. United Nations 
Environment (UNEP 2011), includes clean coal and larger-scale hydro as part of their National Strategic Plan on Green Growth (NSPGG 2013-2030) in the energy sector. Meanwhile, the lack of a proper renewable energy strategy and targets undermine the potential of a sustainable energy transition in Cambodia (Vuola et al. 2020, ADB 2018, MoE 2013, Poch, 2013, Kimura \& Phoumin, 2019).

In Cambodian households, traditional fuels, mostly firewood, are the most common source of energy (Ferranti et al. 2016; Phoumin et al. 2020; San, Spoann, et al., 2012; San, Sriv, et al., 2012; World Bank, 2018). It has been estimated by Phoumin et al. (2020) that the reliance on biomass as an energy source in the residential sector nationally still remains at around $87 \%$, whereas a study by San, Sriv, et al. (2012), San, Spoann, et al. (2012)) found up to $96 \%$ of sampled households using fuelwood for daily activities in Kampong Chhnang province. Petroleum fuels, mostly kerosene and liquid gas, are mostly used with more efficient burners than solid fuels such as firewood. Traditional fuels tend to be inefficient, and burning them releases air particulates that are harmful to human health (e.g. Phoumin \& Kimura, 2019). Collection of the fuels takes time away from productive work and may contribute to deforestation and forest degradation if not well managed, linking it to a range of broader ecological and climatological issues (Phoumin et al. 2020). Reliable access to adequate energy is universally seen as one of the crucial factors of development and a precondition for meeting basic human needs. Furthermore, deforestation is a continuing problem in Cambodia, thus making it harder to find firewood and posing a serious problem to energy security (Ehara et al., 2016). Rural households in Cambodia are still very reliant on natural resources both for energy source and income (Nguyen et al., 2015). Phoumin and Kimura (2019) found that the negative impact of energy poverty, associated with biomass use, on household wellbeing in Cambodia is enormous, both in terms of health, education, and income. Cambodia suffers also from one of the highest electricity prices in the region with a price reaching even as high as $\$ 1 / \mathrm{kWh}$ from private electricity providers (Phoumin \& Kimura, 2019, ADB 2018, World Bank, 2018)).

The aim of this article is to analyse the current situation of access to energy (in relation to SDG 7) and energy usage behaviour in households in two provinces in Cambodia, namely Pursat and Kampong Cham. The paper provides information on the differences in rural and urban energy profiles, and the most common energy sources used in different wealth groups in both electrified and non-electrified areas in the sampled provinces. The assumption of the study is that more urban and higher income groups favour electricity over biomass. We analyse the assumption against the energy profiles on the basis of two conceptual energy models - the energy ladder and energy stacking models-in relation to energy behaviour in Cambodian households in forest rich and forest scarce provinces. This is followed by a discussion of the findings in light of the most recent studies. Finally, the new knowledge created in this study is brought into the discussion to better understand, support, and complement previous research findings on the complexities of energy usage patterns that can be used for designing and developing energy services to promote the transition towards more sustainable energy systems for all in Cambodia.

\section{Background: conceptual energy models and energy use in Cambodia}

According to the classic energy ladder concept, households in developing countries will move to more modern energy sources as their economic situation improves (e.g. Leach, 1992, Hosier et al. 1987). The energy ladder concept depicted in Fig. 1 shows energy 


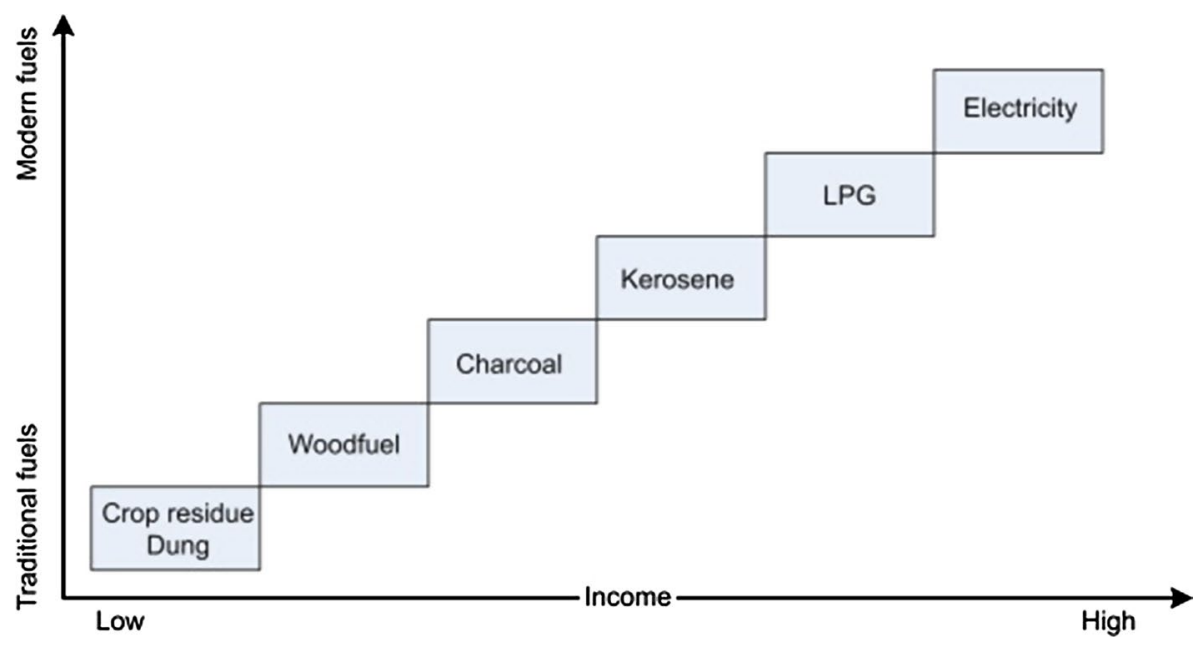

Fig. 1 The classic energy ladder. (Kowsari \& Zerriffi, 2011)

sources classified into traditional and modern fuels, and their relationship with income levels. Based on this concept, the availability, level of access, and cost of different fuels affect energy choices. Traditional fuels (i.e. plant residues, dung and firewood) are affordable, but collection and cooking are time consuming. Inefficient burning (associated with traditional cook stoves) may cause health issues such as respiratory and eye diseases. Liquefied Petroleum Gas (LPG) and electricity, for instance, are harder to get but more efficient, clean to use, and convenient to store (Leach, 1992).

The energy ladder concept is often criticized as being a too simplified theory (e.g. Daioglou et al. 2012; Ekholm et al. 2010; Kowsari \& Zerriffi, 2011). For example, it assumes that as households get wealthier they abandon the inferior fuels, whereas according to Kowsari and Zerriffi (2011) this contradicts empirical studies (e.g. Heltberg 2004; Hosier et. al. 1987; Masera et al. 2000). Instead of changing energy sources, old ones are complemented with new, thus energy options accumulate in households as they get wealthier; a concept known as the energy stacking model (Fig. 2) (Adamu et al. 2020; Kowsari \& Zerriffi, 2011).

Kowsari and Zerriffi (2011) list multiple reasons why households do not give up traditional fuels; for example, they provide security when modern energy supplies fail (ESMAP 1999) and when prices fluctuate (Leach, 1992). Furthermore, new sources might be inapplicable to habitual or traditional cooking methods and preferences (ESMAP 2003; Masera et al. 2000). Modern energy sources are often thought to be expensive, which prevents people from completely counting on them (Davis, 1998, Phoumin et al. 2020, ADB 2018, World Bank, 2018). Often, households might rely on traditional fuels but use modern sources in small amounts for specific purposes (Victor, 2002). It is also common to switch back to use traditional fuels after adopting new energy sources (Adamu et al. 2020; Kroon et al. 2013; World Bank, 2018). For example, Wickramasinghe (2011) found that in Sri Lanka many have reverted to firewood after the price of LPG increased, and Ekholm et al. (2010) have found in India that the rural population relies mainly on traditional fuels even with increased incomes. In Cambodia, Phoumin et al. 2020 found the high cost of modern energy sources to be the reason for households' continued use of traditional biomass. 


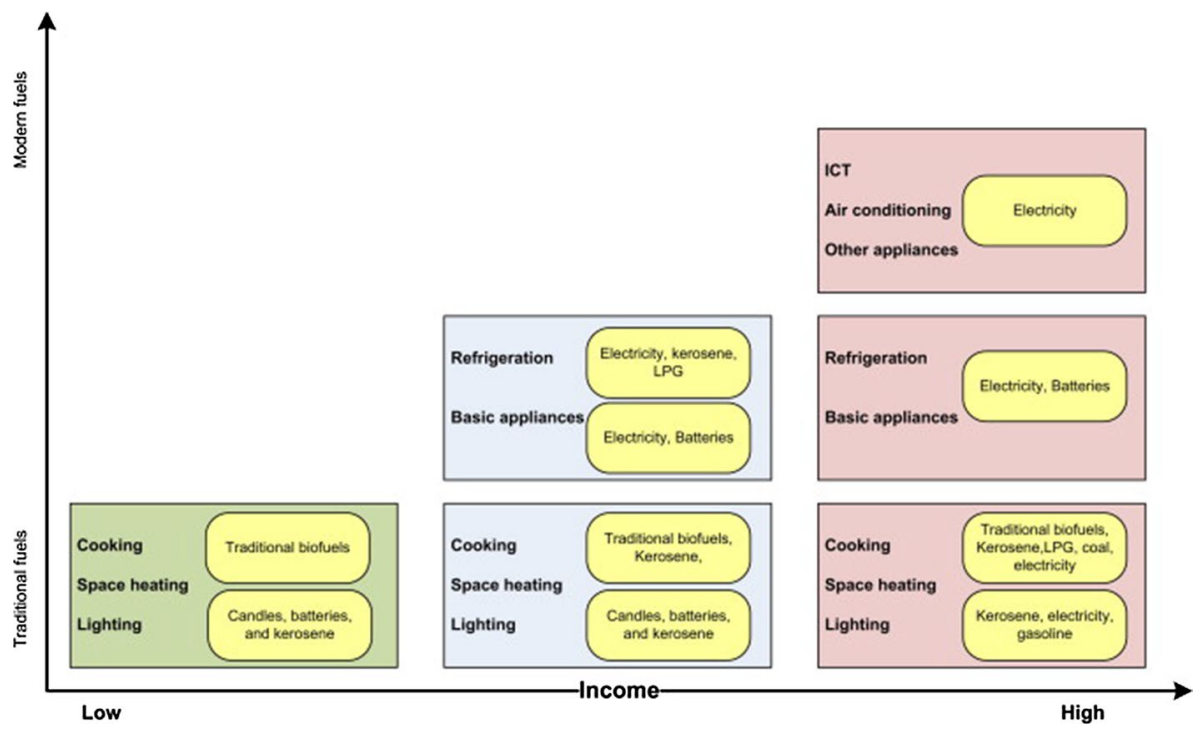

Fig. 2 The energy stacking model (Kowsari \& Zerriffi, 2011)

The energy stacking model emphasizes the role of income as a determinant when choosing fuels. Kroon, Brouwer and Beukering (2013) describe a framework that tries to clarify the determinants influencing household energy choices. They divide the determinants into three categories: "(i) the household external biophysical environment, (ii) the household external political and institutional-economic decision context, and (iii) the household internal opportunity set" (Kroon et al. 2013). The third category contains many different factors that have been tested in various studies. These are, for example, the size of the household, cultural habits, attitudes, preferences, the age of the household head, education and of course the income (e.g. Ekholm et al. 2010, Pachauri, 2004, Kowsari and Zerrifi 2011, Kroon et al. 2013, Luukkanen, 1991, Adamu 2020, Phoumin et al. 2020). There are also differences within the same income groups depending on whether the income is regular or not, whereby households with regular wages are more likely to use LPG (Heltberg, 2005, according to Kroon et al. 2013). There are also somewhat conflicting results in studies carried out in different locations, for example in relation to house ownership and household size (Kroon et al. 2013).

The second of the three determinant categories (Kroon et al. 2013) is based on household external factors such as energy access and price. For example, wood scarcity may force households to adopt other energy sources while high or unstable prices of modern fuels may reduce their attractiveness. The first category includes external biophysical factors that a household has to function with; e.g. climate, geographic location (Kroon et al. 2013). According to various research (e.g. Pachauri, 2004, Phoumin et. al 2020, World Bank, 2018), household economics are indeed the most important factor, but the location (i.e. whether rural or urban) has also been found to be significant for energy consumption patterns. This is partly overlapping with the other categories because the differences of the geographic areas arise from their characteristics and the living conditions and culture. Biomass is usually easier to collect in rural areas, while in cities the supply of modern energy sources is better (Elias \& Victor, 2005; Phoumin \& Kimura, 2019; Phoumin et al. 2020). In 


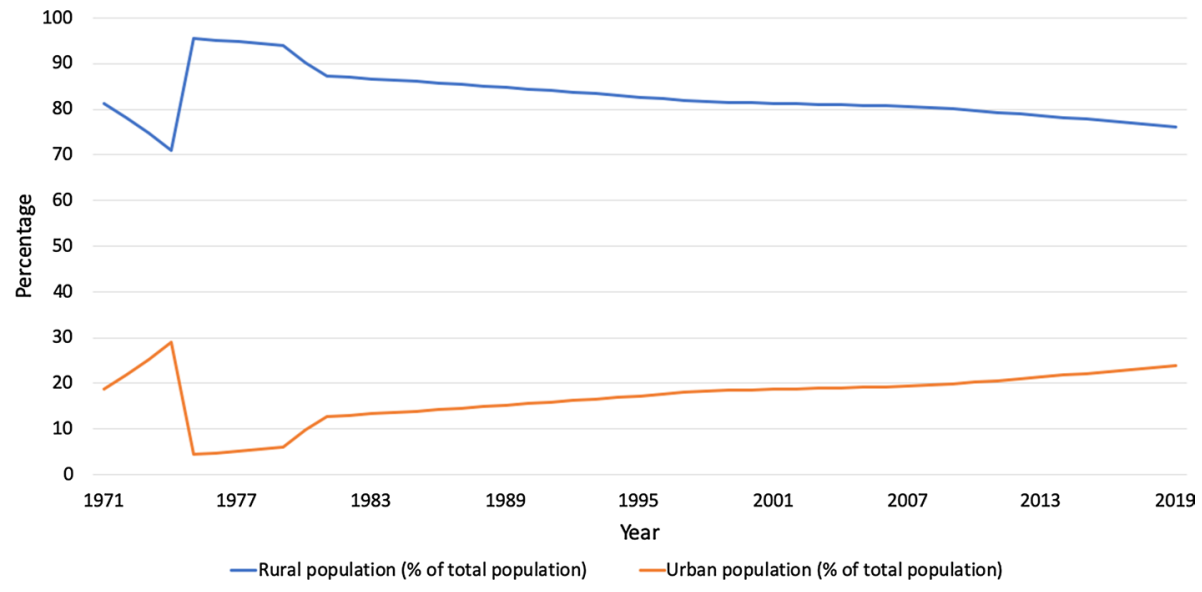

Fig. 3 Population development in urban and rural areas between 1971 and 2019 (\% of the total population). (World Bank 2021)

rural regions, moving up the energy ladder can also mean a transition from self-sufficiency to market dependence (Kroon et al. 2013).

\subsection{Energy use situation in Cambodia}

The population in Cambodia in 2015 was estimated to be about 15.6 million (UNDESA 2015). The mostly rural Cambodia experienced a rapid urbanization in the 1960's, but after the Khmer Rouge took power in 1975 the urban population collapsed from 29 to $4 \%$ in only one year. Figure 3 illustrates the share of gradually increasing urban population, yet the share of the urban population still has not reached the level of 1974.

According to the Ministry of Mines and Energy of Cambodia (2020), Cambodia's Total Final Energy Consumption (TFEC) has increased about 7.2\% per year between 2010 and 2018 , while the growth rates of commercial energy—such as oil and electricity-were similarly $8.1 \%$ and $18.3 \%$ per year respectively. Biomass remains the most used energy source in the residential sector, and to some extent in industry and electricity production. The biomass share of TFEC was $25.5 \%$ in 2018, which has significantly decreased from 2010 when the value was $40.9 \%$, and is expected to be replaced by commercial energy such as oil and electricity (Ministry of Mines and Energy of Cambodia 2020). Based on Kimura and Han (2019), TFEC is expected to double in 2015-2040, with industry sector growth rate of 3.5\%, reaching 2.41 Mtoe in 2040 and residential and commercial sectors energy demand growing approximately $2 \%$ in 2015-2040, reaching 5.67 Mtoe in 2040, an increase from 3.45 Mtoe in 2015.

The World Bank statistics on Cambodian access to electricity show that in 1991 less than $1 \%$ of the population had access to electricity, whereas the share was more than half (56\%) in 2014, and by 2019 over 90\% (World bank 2019, Energypedia, 2021). According to the World Bank, in 2018 nearly all urban Cambodians had access to electricity, while in rural areas the number was almost $90 \%$. Access rates are presented in Fig. 4. The annual fluctuations of statistics may be a result of diverse measurement practices, or based on the definitions of urban or rural areas in different years (World Bank 2021). 


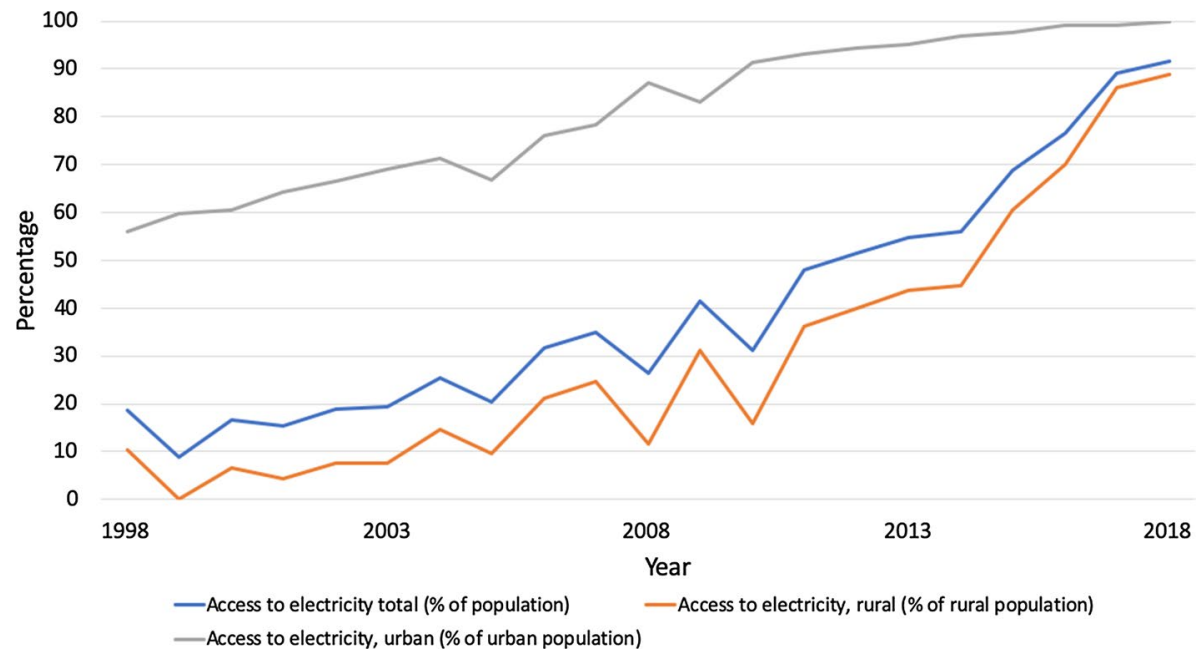

Fig. 4 Access to electricity in Cambodia in rural and urban areas in 1998-2018 (\% of the population). (World Bank 2021)

According to the World Bank (2018), nearly all of Cambodia's population (97.6\%) have access to at least one source of electricity $(71.5 \%$ on the grid, and $26.1 \%$ off the grid electricity), approximately one tenth of the rural population still remains without modern access (World Bank 2021). Energy poverty is around 33\% nationwide and persists especially among the rural population (Phoumin \& Kimura, 2019). In addition to access to grid quality electricity, the use of batteries still remain very common even in the cities with lower income groups. Addressing the challenge of rural electrification depends largely on government priorities and the emphasis on equal access to all modern energy sources (e.g. ADB 2018; Phoumin et al. 2020).

\section{Materials and methods}

\subsection{Sampling sites}

This article is based on a quantitative household survey carried out in late 2015 and specifically looks into the second and the third categories suggested by Kroon et al. (2013) with an emphasis on urban-rural status, access to the electricity grid and household incomes. The survey consists of a sample of 970 households from two provinces. The primary sampling units, namely Pursat and Kampong Cham provinces, were selected by purposive sampling based on two main aspects; (1) differences e.g. in their economic structure, sources of livelihoods and wealth levels, geographical features and abundance of forest resources as well as population densities and urban-rural divide; and (2) complementarity of the two provinces (due to the differences) in representing the diversity of the country better than two similar provinces.

Pursat is located in western Cambodia, from the west side of Tonle Sap Lake to the border of Thailand (Fig. 5). Most of the province, specifically the southern and western parts, are forest covered mountains. Big parts of the forest are protected as wildlife sanctuaries 


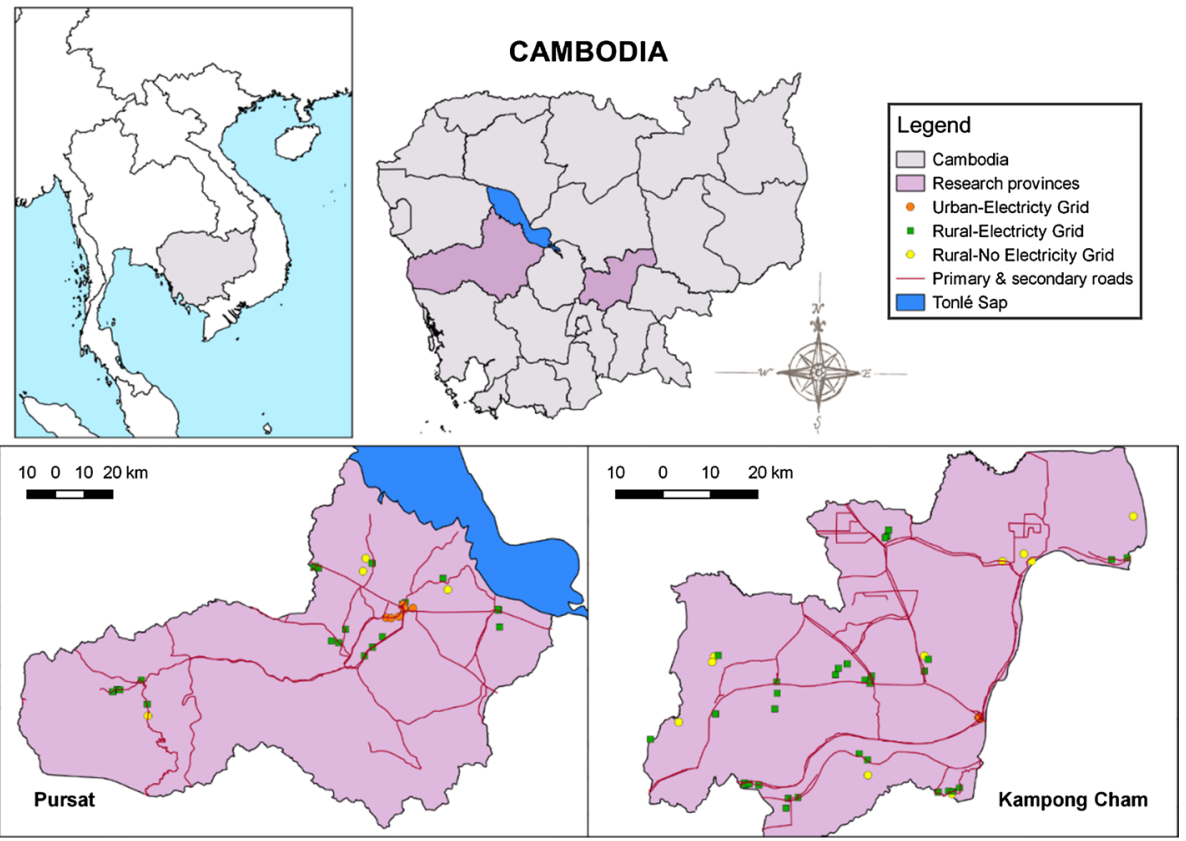

Fig. 5 The two study provinces, Pursat and Kampong Cham, and study villages marked according to the access to electricity (Map by Adrian Monge Monge, in Kallio et al. 2019)

of Phnom Samkos and Phnom Aural, and the protected forest of Central Cardamom (SCW 2006). The lowlands and the fertile flood plain is used mostly for paddy rice farming, whereas the soil in the rest of the province is less fertile than in Kampong Cham. Fisheries in Tonle Sap Lake is one of the most important livelihood activities. The forests in Pursat, especially in the Cardamon mountains, are thick and located in rugged terrain, making them hard to utilize. The topography also has an effect on energy access, with mountains hampering grid extensions and collection of firewood.

Kampong Cham, on the other hand, is located in central Cambodia, west of the Mekong River (Fig. 5). In contrast to Pursat, the province is composed mostly of fertile lowlands that are mostly used for agriculture. There are also some shrub areas and small forests in the northeast corner of the province (SCW 2006). Kampong Cham, as one of the most populated provinces in the country, has a larger population $(1,128,110$ inhabitants) and population density $\left(247\right.$ people $\left./ \mathrm{km}^{2}\right)$ than Pursat $\left(487,819\right.$ inhabitants, 38 people $/ \mathrm{km}^{2}$ ) (Ministry of Planning and National Institute of Statistics 2017). Kampong Cham is one of the wealthiest provinces of Cambodia, while Pursat is one of the poorest. This is evident in the poverty rate, with 17\% in Kampong Cham and 23\% in Pursat in 2014 (Royal Government of Cambodia, 2015). Based on the desk analysis carried out by the survey team, good road access coupled with market options and export possibilities to Vietnam have enabled a substantial industrial sector to operate in Kampong Cham. Besides processing factories, rubber and agricultural plantations are more common for export in Kampong Cham. Kampong Cham has various hydro-electric power plants and is connected to the national and regional electricity grids to Vietnam.

According to Global Forest Change maps (developed by Hansen et al. 2013) both surveyed provinces have experienced a remarkable forest cover decrease in all canopy 
categories between 2000 and 2016. This is especially evident in Kampong Cham where forests with dense canopy (>75\%) have diminished fast, over $70 \%$ loss since 2000 and even in the sparse forest $42 \%$ loss in the same time period. The forests in Pursat are still abundant and multifold in size compared to Kampong Cham, although similar trends are also seen in all canopy categories (Hansen et al. 2013).

\subsection{Sampling methods, sample size determination and data collection}

The study utilizes multistage sampling according to Probability Proportional to Size (PPS), which is commonly used in multistage population sampling (e.g. Skinner, 2014). Three determinants were used to select the study villages, namely: province (with differing levels of development), level of urbanization (rural/urban), and access to electricity (connected to the grid/not connected to the grid). As a result, each village could be categorized as being either urban electrified, electrified rural, or non-electrified rural. The sample was equally distributed across the two provinces, after which proportional random selection and proportional household quotas were calculated for districts, communes and different village types. Within villages, the households were selected using a skip interval proportional to village population from a random starting point. For analytical purposes of this article, the households were classified as rural $(n=875)$ or urban $(n=95)$, with three wealth classes (lower $=309$, middle $=405$ and higher $=256)$, and electrified $(n=669)$ or non-electrified $(n=301)$.

Communes were stratified under "Urban and Rural" categories based on the 2008 census (NIS and Ministry of Planning 2008). Furthermore, the electricity distribution map was used to identify communes with/without electricity coverage. Communes and villages were selected at random by Probability Proportional to Size (PPS), forming the elementary sampling units. A quota of 450 households (representative sampling unit) for each province was set according to PPS to district, commune, and village level until reaching saturation of 970 households in total. Systematic random sampling with skip interval proportional to population was used for selecting the households in both urban and rural areas.

The research questionnaires were designed and field tested in households prior to commissioning the total sample. Different sections were further elaborated based on the feedback received from the households and the interviewers. A total of 970 semi-structured household interviews (in 78 villages located in the two study provinces) were conducted in late 2015 to collect primary data on the socioeconomic characteristics of the household, their livelihood strategies, energy use, health-related questions, access to forest resources and land, and changes in the communities as perceived by the households. The selection of semi-structured interviews allowed the respondents to add relevant information that was not part of the predetermined questions to bring out any other factors they considered important. The data obtained from interviews was cleaned, coded, and analysed statistically with Statistical Package for the Social Sciences (SPSS). The sample size allowed disaggregation into sub-samples that would remain statistically significant: the most common independent variables used in the analysis were the location (Pursat or Kampong Cham province), household access to electricity (urban, electrified rural, or non-electrified rural area) and wealth levels, as shown in Table 1.

All urban areas in the sample are electrified by the grid. In the rural areas, there are communes that use local solutions to produce electricity, for example, solar home systems (Department of Rural Electrification Fund, 2016). Therefore in some non-electrified areas 
Table 1 Description of the provincial, urban/rural, electrification and wealth variables in the sample

\begin{tabular}{lll}
\hline & Frequency & Percent \\
\hline Province & 970 & $100 \%$ \\
Pursat & 499 & $51 \%$ \\
Kampong Cham & 471 & $49 \%$ \\
Urban/Rural/access to electricity & 970 & $100 \%$ \\
Urban electrified & 95 & $10 \%$ \\
Rural-electrified & 574 & $59 \%$ \\
Rural non-electrified & 301 & $31 \%$ \\
Wealth groups & 970 & $100 \%$ \\
Higher & 256 & $26 \%$ \\
Middle & 405 & $42 \%$ \\
Lower & 309 & $32 \%$ \\
\hline
\end{tabular}

households claim they are connected to the grid $^{1}$ or in some cases parts of the communes have access to the grid (e.g. border regions in the districts).

Household wealth groups were defined by the respondents' type of housing and assets they own, as estimating monetary monthly incomes from multiple income sources was found challenging, especially in rural settings. The housing types were classified according to the building materials. The assets owned by the households included, for example, physical assets such as livestock, or vehicles, among others. Based on the information about the housing standards and the total value of their assets, the wealth status of households was calculated using the following equation:

$$
A=\Sigma a i b i+c
$$

ai: the number of assets owned by each household

bi: average market price of each corresponding assets

c: average corresponding price of the housing standard

Thereafter all households were divided into three wealth groups: lower, middle, and higher as follows:

If $\mathrm{A}<5,500$ USD: lower wealth status

If $5500<\mathrm{A}<18,000 \mathrm{USD}:$ middle wealth status

If $\mathrm{A}>18,000$ USD: higher wealth status

The random sample of households from different wealth groups is presented in Fig. 6. In general, the sample consisted of more middle wealth group respondents in Pursat and less variation between urban electrified and rural non-electrified areas. In Kampong Cham the electrified urban areas seem to be relatively wealthier, with $68 \%$ of the households in the higher wealth group, and only $4 \%$ of the households in the lower wealth group. However, in the rural areas, the lower wealth groups are clearly more dominant. In Kampong Cham the highest wealth group represents one third while in Pursat the share is one fifth of the total sample.

\footnotetext{
1 In the survey data there are four areas classified as non-electrified, yet in reality, in three of these areas households claim to consume electricity from the grid (10-45\% of total energy use).
} 


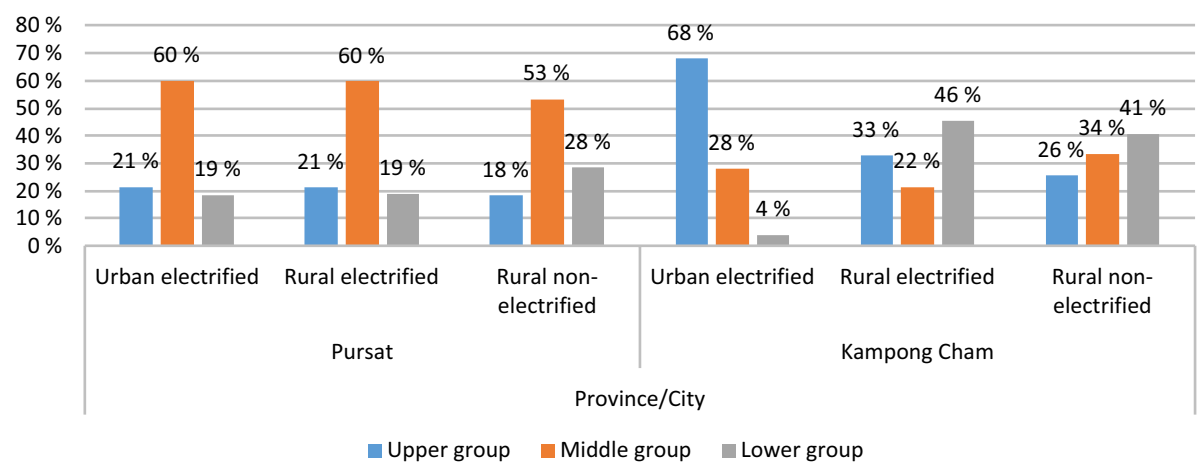

Fig. 6 Wealth groups in different provinces and areas

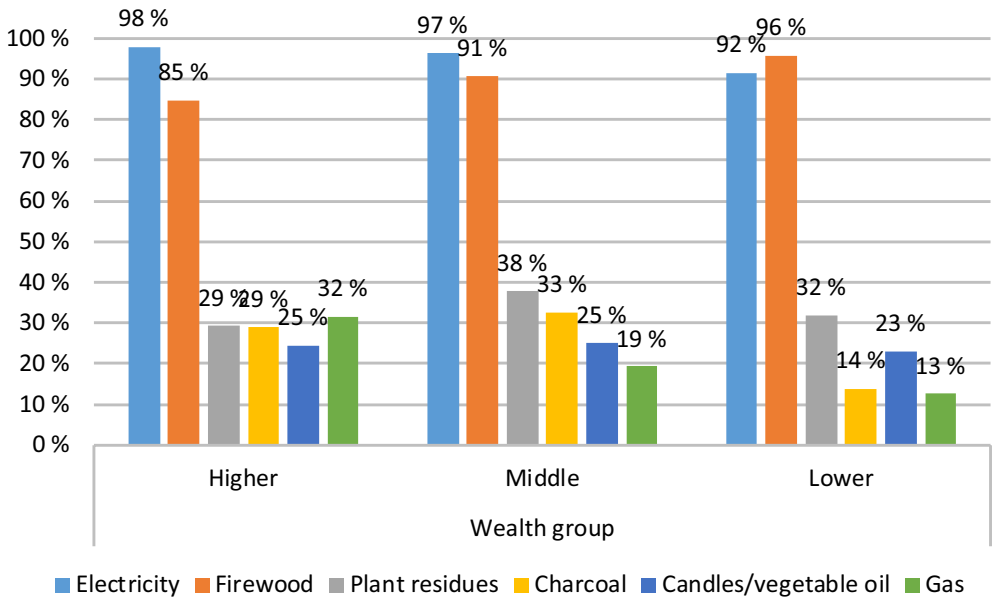

Fig. 7 Most common energy sources in wealth groups

\section{Results of household energy use}

Electricity is the most common energy source used in Pursat and Kampong Cham households, with over $95 \%$ of respondents using it at least to some extent (Figs. 7 and 8). Figure 7 shows that $98 \%$ of households in the higher wealth group and $97 \%$ of households in the middle wealth group use electricity. It is marginally less common in the lower wealth group, where $8 \%$ do not use it at all. The difference between various wealth groups and electricity usage is significant $(p=0.000)$. The clearest difference is in electrified rural areas, where the gap between the higher and lower wealth groups is nearly $9 \%$ (see Table 2). Yet there is no clear significant difference between the electricity use in rural and urban areas $(p=0.054)$, thus electricity is used equally in both areas (Fig. 8).

Almost $91 \%$ of all respondents use firewood, and the frequency of use is linked with wealth level (Fig. 7). Approximately $85 \%$ of the higher wealth group said they use firewood in comparison with $91 \%$ and $96 \%$ respectively in other lower wealth groups $(p=0.000)$. Figure 8 indicates that location strongly influences firewood usage. In 




Fig. 8 Most common energy sources in urban and rural areas

Table 2 Percentage of households using a certain energy source in different areas and wealth groups. (Cambodia 2015)

\begin{tabular}{|c|c|c|c|c|c|c|c|c|c|}
\hline \multirow[t]{2}{*}{ Energy source } & \multicolumn{3}{|c|}{ Urban electrified (\%) } & \multicolumn{3}{|c|}{ Rural electrified (\%) } & \multicolumn{3}{|c|}{$\begin{array}{l}\text { Rural non-electrified } \\
(\%)\end{array}$} \\
\hline & Higher & Middle & Lower & Higher & Middle & Lower & Higher & Middle & Lower \\
\hline Electricity & 100 & 100 & 100 & 98 & 96 & 89 & 97 & 96 & 95 \\
\hline Firewood & 47 & 69 & 86 & 87 & 91 & 96 & 98 & 98 & 97 \\
\hline Plant residues & 13 & 37 & 50 & 33 & 36 & 33 & 30 & 41 & 29 \\
\hline Charcoal & 59 & 67 & 71 & 31 & 34 & 13 & 9 & 18 & 7 \\
\hline Candles/vegetable oil & 25 & 41 & 21 & 31 & 27 & 28 & 9 & 17 & 13 \\
\hline Gas & 81 & 45 & 29 & 31 & 19 & 17 & 8 & 10 & 3 \\
\hline Kerosene & 3 & 2 & 0 & 10 & 11 & 11 & 13 & 12 & 10 \\
\hline $\begin{array}{l}\text { Petrol/diesel for irrigation } \\
\text { pump }\end{array}$ & 3 & 10 & 7 & 6 & 8 & 6 & 6 & 5 & 9 \\
\hline Solar Panel & 0 & 0 & 0 & 2 & 3 & 0 & 14 & 8 & 3 \\
\hline Animal Dung/Biogas & 0 & 0 & 0 & 1 & 1 & 1 & 0 & 2 & 1 \\
\hline
\end{tabular}

non-electrified areas, $98 \%$ of respondents use it whereas in urban areas the rate is $64 \%$. Furthermore, the study finds that $73 \%$ of households collected firewood, whereas only $20 \%$ purchased firewood from markets. The difference in collecting firewood is evident between urban, electrified rural and non-electrified rural areas $(p=0.000)$. In non-electrified areas, almost $90 \%$ of respondents collect firewood, whereas the corresponding figures are $78 \%$ in electrified rural areas and only $54 \%$ in urban areas.

Energy usage patterns are quite similar in both provinces, as can be seen in Fig. 9. However, plant residues - especially charcoal use-is more common in Pursat, while gas is used slightly more often in Kampong Cham. 




Fig. 9 Most common energy sources in Pursat and Kampong Cham

In the non-electrified rural areas, all wealth groups use a lot of firewood (See Table 2). The differences between wealth groups are most interesting in urban areas where under half $(47 \%)$ of the urban households in the higher wealth group use firewood for energy, while in the rural non-electrified areas nearly all of the higher wealth households (98\%) are using firewood. Hence it seems both the wealth class and especially the location have an influence on firewood usage.

The same tendencies can be seen in the use of plant residues, with $34 \%$ of all households using them as an energy source. There is however no correlation between plant residue usage and wealth groups $(p=0.060)$ or location $(p=0.768)$. If looking at plant residue use only in urban areas, it has a correlation with wealth group $(p=0.016)$. Urban lower wealth groups use plant residues more than the middle wealth group, and the middle wealth group clearly use more than the higher wealth group (Table 2). In Pursat, $40 \%$ of the respondents use plant residues while in Kampong Cham only 27\%. In Pursat, the use increases as household wealth gets lower, but in Kampong Cham the middle wealth group uses plant residues as an energy source the most.

The fourth most common energy source is charcoal, with $26 \%$ of households across all sites using it. As Fig. 8 shows, household location influences its use, with $65 \%$ of urban households using charcoal, $26 \%$ in electrified rural areas, and $13 \%$ in non-electrified rural areas. Charcoal usage is also dependent on wealth group $(p=0.000)$, with middle wealth group respondents using more charcoal (33\%) compared to the higher and lower wealth groups (29\% and 14\% respectively) (Fig. 8). Charcoal is also more common in Pursat (37\%) than in Kampong Cham (14\%).

The use of gas correlates both with the wealth group and urban-rural location $(p=0.000)$. The use of gas increases strongly from lower to higher wealth groups and from non-electrified rural to urban regions (Figs. 7, 8). In other words, the difference between lower wealth group households in less developed rural areas and higher wealth groups in urban areas is huge: in the first case, the gas usage is only $3 \%$ while in the latter it is $81 \%$. Even when only looking at the lower wealth group gas usage in urban and different rural regions, the value grows tenfold (Table 2). In Kampong Cham 23\% of respondents use gas, which is slightly more than in Pursat, where the value is $18 \%(p=0.040)$. 


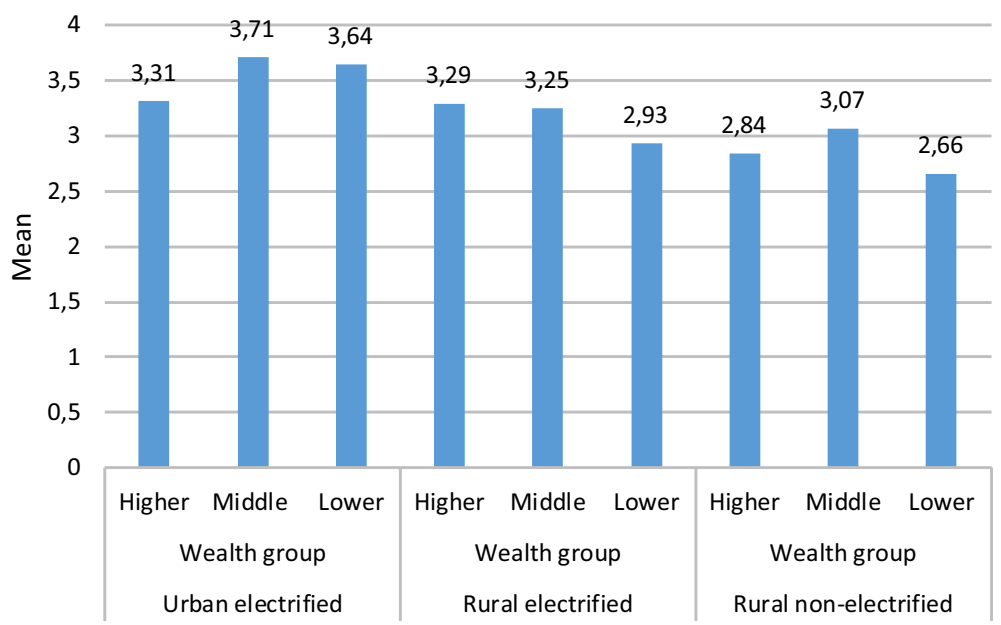

Fig. 10 Mean number of different energy sources used by different wealth groups and locations

Kerosene and solar panels are used more in rural areas (see Table 2). It is likely that they are used to compensate electricity for lighting purposes. In rural areas, electricity originates mainly from charged batteries. Other lighting options, such as kerosene or solar home systems, are also seen as viable alternatives.

Although there are almost $20 \%$ more gas users in the higher than in the lower wealth group, there is only $10 \%$ less firewood usage in the higher wealth group. That means that the majority of respondents who have switched to use more modern energy sources also continue to use traditional sources. To put it more accurately, $28 \%$ of gas-using households do not use firewood anymore, but $72 \%$ are using both sources. As almost every household is using electricity, the correlation is not evident.

According to the survey data, the higher wealth group is using an average of 3,18 different energy sources while the lower wealth group is using only 2,88 (Fig. 10). However, the middle wealth group is using the most varied kind of energy sources, with an average of 3,25 sources. In urban areas, households have the broadest variety of energy sources, 3,57 on average. In electrified rural areas the value is 3,16 and in non-electrified areas even smaller, 2,88. The joint effect of wealth groups and household location to the number of used energy sources is shown in Fig. 10. In urban areas, households use more energy sources than in rural settings. The use of plant residues and charcoal is most common within the urban lower wealth group. In the Welch Test for equality of means, there is a correlation between the mean values and wealth groups living in rural, electrified rural, or non-electrified rural areas $(p=0.000)$.

Survey analysis from Pursat and Kampong Cham provinces show that households are using energy mostly for cooking and lighting, but also for heating, cooling, communication and entertainment.

\subsection{Electricity sources and usage}

As stated previously, nearly all respondents use electricity in some way, but sources vary. Most purchase it from the grid or use batteries. Electricity from the grid is usually more affordable, while charging batteries is time-consuming. 


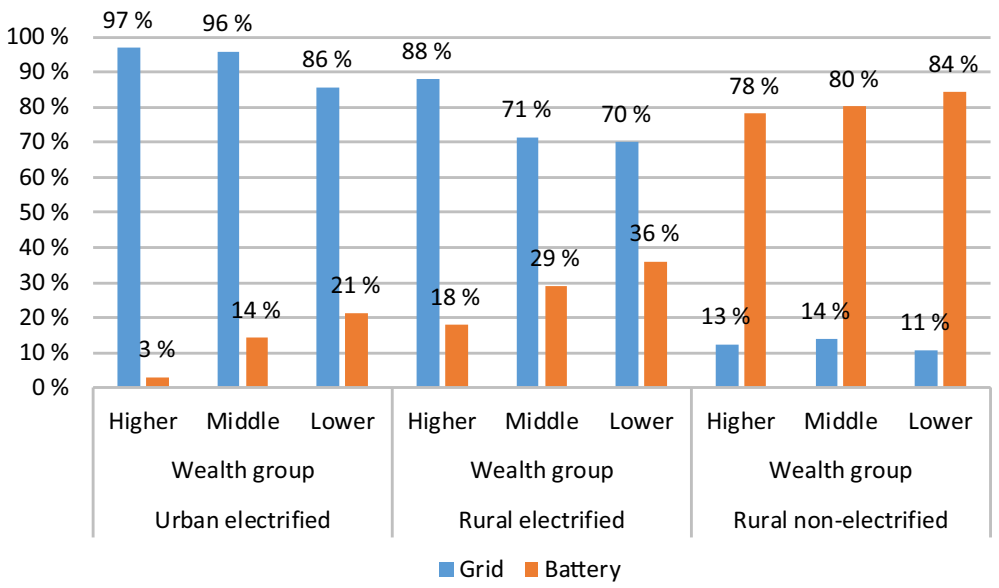

Fig. 11 Source of electricity in wealth groups in different areas, \% share of all households

According to the survey data, about $58 \%$ of the surveyed households get electricity from a local or national grid, which is compatible with World Bank data from 2017 (56\%). Batteries are also a common source of electricity, with $43 \%$ of respondents using them. Only $4 \%$ of respondents are using solar PV systems. Diesel, petrol generators and household or village-scale hydropower generators are even more rare. InPursat, there are off-grid communes where over half of the respondents reported having access to electricity. ${ }^{2}$ A report by the Department of Rural Electrification Fund (2016) reveals that these communes have had solar home systems installed in 2015. Thus responses from non-electrified areas, where residents claim to use grid electricity, are also included in the analysis.

This study finds that the source of electricity depends on the wealth group when comparing grid and batteries. Approximately $85 \%$ of all respondents use either battery or grid, $8 \%$ use both of these as electricity sources and $7 \%$ use neither. Grid electricity is more commonly used within the higher wealth group, while batteries are more commonly used in lower wealth groups (see Fig. 11).

In urban electrified and non-electrified rural areas there is also a significant difference in the use of electricity sources (Fig. 11), which highlights the strong dependence on batteries in the rural non-electrified households and reliance on the grid in the urban electrified households. Batteries are in use in $81 \%$ of the non-electrified households, and $8 \%$ use solar panels. Batteries remain common in rural electrified areas but only $2 \%$ of households are using solar panels. In urban areas batteries are in use mainly by the lower wealth groups. Almost $95 \%$ of urban households and $76 \%$ of households in electrified rural areas rely on grid electricity. As with traditional fuels, there are no big differences in electricity sources used among different wealth groups in the non-electrified rural areas, i.e. almost everyone has to use batteries for electricity (Fig. 11) in the absence of the grid.

${ }^{2}$ This may be due to small electricity generating facilities, border regions of the commune/district. 


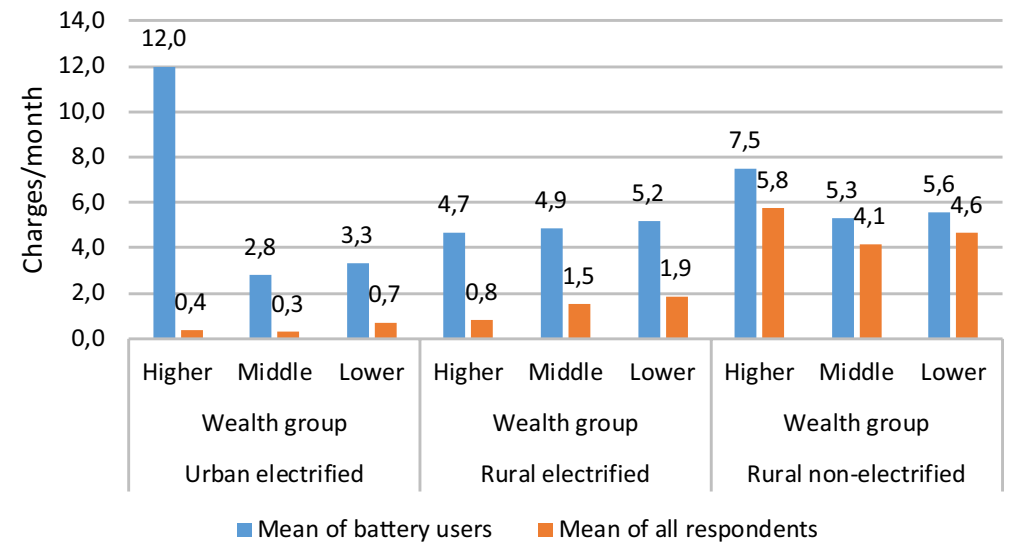

Fig. 12 Number of battery charges/month



Fig. 13 Electricity bought from the grid, kWh per month

Battery charging (full charge/month) in different wealth groups in rural and urban areas is presented inFig. 12. ${ }^{3}$ Batteries are used more in rural areas, and especially in non-electrified rural areas, and in particular among the lower wealth group. Furthermore, the mean value of charging incidence among battery users shows that rural people are more reliant on them than in urban areas, with relatively few households using batteries (10\% of middle and $7 \%$ of lower wealth groups are using both batteries and grid, while $73 \%$ of households in the higher wealth group use only grid and $3 \%$ only batteries). In electrified rural areas, more households rely on both grid and batteries (18\% lower, $7 \%$ middle, and $9 \%$ higher wealth group). There is also a correlation between the frequency of battery charging and

3 The first bar presented in Fig. 12 in the urban higher income group is based on only one household in the sample, and that one household charged batteries twelve times per month. 
location ( $p=0.021)$. However, the correlation cannot be seen between the number of charging times and wealth groups $(p=0.311)$.

Urban households in the higher wealth group use a significantly higher amount of electricity from the grid than the other wealth groups in other locations (Fig. 13). Their average use is $104 \mathrm{kWh}$ per month, which is over three times more than the higher wealth group in rural electrified areas or the urban middle wealth group (both $34 \mathrm{kWh}$ per month). Again, the differences among wealth groups are most significant with urban respondents. In rural non-electrified areas, the mean is substantially lower and only a few households connected to an electricity grid account for the higher amounts of electricity used. The mean of all respondents in Fig. 13 shows that grid electricity is used more in urban and electrified rural areas and within higher wealth groups. There is a correlation between grid electricity use amounts and both wealth groups and household location in urban or different rural areas $(p=0.002$ in both cases).

Fans, mobile phones, energy saving lamps, and televisions have high penetration rate in both provinces. In Kampong Cham the profile of the electrical device penetration rate is similar to Pursat, for instance, in the urban area penetration rate is higher than in rural areas. However, in Kampong Cham households own more electrical devices than Pursat. Similarly, in urban areas the penetration rate is higher than in rural areas. Higher income groups tend to have the most electrical appliances, while penetration rates in other income groups is relatively low. In conclusion, wealth group - regardless of location-is an important parameter determining purchase behaviour of electrical devices. The survey also reveals that electricity is clearly used more to first improve living conditions and for entertainment purposes, rather than to support economic activities.

\section{Discussion}

This article describes household energy consumption patterns in two provinces in Cambodia. It is important to emphasize that local environmental and socio-cultural conditions vary considerably between the studied provinces, and that the descriptive results should not be generalized as such to other provinces of Cambodia.

The survey results are compatible with both the energy ladder and stacking models, but do not fit perfectly to either theory. We can note that progress with energy ladders is not linear, but rather it is a complex process, where also regression back to previous steps of the ladder is possible. This finding is also supported by Daioglou et al. (2012) and Adamu et al. (2020) with results showing the fine balance of costs in relation to the selected energy source, and always with a mix of energy sources rather than a complete fuel substitution. Examining how different wealth groups use various energy sources tested the validity of these theories. Although households may have had more modern energy sources they did not abandon the old ones, but rather this resulted in using a broader pool of energy sources, hence supporting the energy stacking model in both urban and rural settings, which was also found by a World Bank study (2018). In addition, determining factors of use of a certain energy source, as found in this study and echoed by other researchers, are the energy costs, availability, and access to funding for modern energy sources, as well as reliability of the energy source (San, Sriv, et al., 2012; San, Spoann, et al., 2012, Phoumin et al. 2019 and 2020, ADB 2018, World Bank, 2018). This manifests evidently in this study whereby in urban areas, households are using more energy sources compared to rural areas, and similarly in higher wealth groups compared to lower wealth groups. The majority of the 
surveyed respondents, regardless of their income or location, who have switched to use more modern energy sources, also continue to use the more traditional sources. The higher wealth group (especially in urban areas) seem to be able to rely more on the new modern energy sources, while middle and lower wealth groups were continuing to use the traditional ones despite modern energy sources being available. The underlying causes here may be distrust and fear of fluctuating prices, or an unreliable grid connection. The access and availability to modern energy sources can be weaker in rural areas and has to be commonly supplemented by batteries for electricity.

Electricity is used in majority of the studied households (95\% of the surveyed households) regardless of the location, wealth or access to electricity grid. It is, however, used mostly for lighting, entertainment, communication and cooling homes with fans, but also somewhat to support income generating activities. The indirect and direct influence on household income and income generating activities is discussed also by Phoumin et al. (2019), showing that electricity significantly influences household income. However as this study found that lower income groups benefit far less (especially in rural areas), if at all, in terms of income generation resulting from access to electricity. This result, however, may be directly linked to the amounts of electricity accessible and affordable due to limiting factors including cost or reliability factors, among others. In our study, income generation activities evidently were of secondary priority only after improved living conditions and entertainment purposes. This is also supported by Bhattacharyya (2012) in their study. The data also reveals the tendency of the higher wealth group to use more grid electricity than other groups. This has been reported also by, e.g. Ekholm et al. (2010) and ADB (2018), and this may increase the opportunities of higher wealth groups to benefit even more from electricity (Phoumin \& Kimura, 2019).

Electrification alone can not be the solution to rural energy access problems, as electricity accounts only for a small share of the energy demand of the studied households, which is also stated in Bhattacharyya (2012). Traditional biomass (firewood mainly) remains the main energy source for cooking in the surveyed households, a finding also mentioned in various other studies (e.g. Bhattacharyya, 2012; World Bank, 2018, San San, Sriv, et al., 2012). Clearly, access to traditional cooking fuels such as firewood cannot be ignored, in spite of their related health, social, and environmental problems (e.g. Bhattacharyya, 2012, Phoumin 2019, World Bank, 2018). Electrical stoves, as commonly used in the Global South, are used only by $4 \%$ of the survey respondents. This finding is consistent with the World Bank (2018) report. The investment costs of these devices are significant, and if the electricity source is not reliable, the consumer decisions of not opting for electric stoves are understandable. Food preparation is one of the most energy consuming activities in households, and a wholesale transition to electric stoves would mean a large rise in electricity consumption, further causing potential problems with production, especially in off-grid areas. Instead of solely looking at electrification, clean and efficient cooking technologies using even traditional biomass sources deserve attention, at least in the interim, as part of the energy transition debate (see e.g. Bhattacharyya, 2012). Cultural aspects of using firewood or charcoal can also not be dismissed either (see e.g. Kroon et al. 2013).

Gas and charcoal are clearly used more in urban than in rural areas due to better accessibility. Charcoal, compared to firewood, takes less storage and is more efficient and less polluting. Eight percent of the charcoal users produce it themselves, while the rest buy it. This is slightly less than found in a 2013 study where $12 \%$ of charcoal was home-made (Lao et. al 2013). Electricity is used more in cities, where $100 \%$ of the respondents use it in one way or another, although electricity is also commoly used in rural electrified and even non-electrified areas, despite the high electricity prices. In the latter, households are 
using mostly batteries, but also local grids and solar panels serve as their source of electricity. These findings are supported in ADB and World Bank studies conducted in 2018. Only firewood and plant residues are a more common energy source in rural than in urban districts. Approximately half of the urban households use firewood, and it is clearly more common in rural areas and in lower wealth groups, where over $90 \%$ of respondents are using it as their primary cooking energy. This resonates especially in Pursat with the abundance of forests in closer proximity to the households than in Kampong Cham. Of all surveyed households, however, $73 \%$ are collecting firewood and $20 \%$ purchased it, which is slightly less than the Lao et al. (2013) study results, with $79 \%$ of firewood collected. As stated in the literature, forests and bushes are usually abundant for wood collection in rural areas, whereas modern fuels dominate in urban areas (see e.g. Elias \& Victor, 2005; Kroon et al. 2013). Furthermore, the differences between wealth groups are most clearly seen in urban areas, where only $38 \%$ of households in the higher wealth group collect firewood.

As this analysis underlines, energy choices are not always straightforward. In Lao et al. (2013) modern fuels are reported as clean, easy, and fast to use. In our study, respondents considered modern fuels to be expensive, and Liquefied Petroleum Gas (LPG) dangerous to use. Charcoal was chosen because it was considered to be safe, easy and clean, yet on the contrary, other repsondents considered it to be unsafe, expensive and difficult to burn. Firewood was perceived as being easy to collect, available, cheap, and easy to burn. However, the health impacts and difficulty to collect were considered drawbacks by respondents, a finding also reported by Phoumin and Kimura (2019). Thus, there is no single optimal energy solution, but rather a combination of different energy sources that fit in the specific local context in Cambodia. Furthermore, accessibility does not always equal to affordability. For example, firewood can also be chosen over other energy sources out of habit or cooking preferences (Jagadish \& Dwivedi, 2018).

This analysis shows that the use of energy sources and wealth levels are connected and inter-linked in complex ways. With the availability of modern energy sources, differences between wealth groups are evident in all locations, and gas and electricity are more common when households get wealthier. Only charcoal makes a minor exception here, as the middle wealth group uses it slightly more than the higher wealth group. Similarly, firewood and plant residues, which are most common in remote rural areas, are more common when household wealth is lower. Phoumin et al. (2020) argue that access alone does not solve the problems of moving away from biomass, but that it is rather a question of household's purchasing power (i.e. ability to spend on electricity). Furthermore, joint analysis with both wealth groups and locations shows that among traditional fuels, wealth indeed has an influence only in the urban areas. Heltberg (2005) states that wealth does not have a significant role in fuel switching in rural areas, which is in line with this study's findings.

In rural areas, poor access to modern energy and the cost of electricity seems to be a significant drag on energy transition. In urban areas, where access to modern energy exists, wealth levels influence remarkably on energy demand. In other words, more wealth also means more use of appliances and more comfort. Phoumin et al. (2020) emphasized that access to electricity, in terms wealth accumulation of households, again places the rural households with limited access and affordability to modern energy in a disproportionally disadvantaged role compared to their urban equivalents.

Our analysis did not evaluate different sources based on their emissions or external impacts, even though that question is critical in Cambodia in the context of high prices, rural energy poverty, and import dependency (Phoumin et al. ). Grid extension is often perceived as a marker for development, yet it may come at a price elsewhere. Realistic projections for future energy demand (including renewable energy support and energy efficiency) 
are in dire need in Cambodia, as mentioned by e.g. Heng and Boyle (2020). In large parts of the Global South, electricity is produced using natural resources on the periphery, and transmitted to cities for the well-off to benefit. This brings also adverse societal development implications and environmental costs.

Finally, as the study shows, rural households with lower incomes seem to benefit proportionally less than others on modern energy services. Various studies (e.g. World Bank, 2018; Phoumin et al. 2020, ADB 2018) that have been referred to here emphasise the challenges with affordability and access. Poor households cannot afford the high prices or the high upfront costs, even if modern energy options are available. Furthermore, as mentioned by Phoumin et al. 2020 and ADB 2018, Renewable Energy Entrepreneurs (REEs) service providers are not able to efficiently benefit from the energy markets as the consumers' purchase power is limited. This in turn strengthens the dependency of households on "cheapbut-dirty" fuels and technologies, as put forward by Diaoglou et al. (2012). These issues cannot be overlooked as they determine how modern energy benefits are distributed, and to whom. Although centralized energy systems are economically attractive, local energy systems are important for self-sufficiency, resilience and sustainability. Technological (intersectoral) diversity has been highlighted as a key feature of sustainable transitions towards less polluting technologies, e.g. by Aldieri et al. (2020). Also the concept of Integrated Community Energy Systems (ICESs) would be a very helpful approach in organizing local energy systems to integrate distributed energy resources and engage local communities. ICESs represent locally and collectively organized energy systems and combine (1) the concept of sustainable energy communities (Schweizer-Ries, 2008), (2) community energy systems (Walker \& Simcock, 2012), (3) community micro-grids (Mendes et al. 2011), and (4) peer-to-peer energy production (Giotitsas et al. 2015). The ICES approach is a relevant approach in rural areas (Koirala et al. 2016), and also in Cambodia. In practice the ICES approach encompasses a wide variety of technologies, organisational arrangements, and potential outcomes, with these desirable outcomes including (1) collective economic returns, (2) reduced fuel poverty, (3) carbon mitigation, (4) greater community cohesion, and (5) an increased knowledge of sustainable energy technologies (Walker \& Simcock, 2012).

\section{Conclusions}

The results show that the Energy Stacking model can be used as a starting point for assessing the sustainability transition of energy sector development in developing country conditions, but it is necessary to realize that conditions are very rarely analogous to this idealized heuristic model. Similarly in this study, the results can provide some generalized direction overall, but are representations of households in two different provinces. The results can, however, help the energy system planners and decision-makers to see the key features of the energy transitions patterns. The critical aspect is the complexity of household resilience behaviour and associated risks of energy sources. Poor households do not have as much resources to take economic risks compared to more well-off households. Our results indicate that in the formulation of energy policies we should pay more attention to resilience of local communities. In practice, this means that renewable energy sources should provide real resilience and fewer risks for local households to reach better sustainability. The data and analysis indicate that there is a correlation between energy access to household location and wealth level in some cases. On the other hand, rural households are 
more self-sufficient, whereas well-off urban households can rely on the national electricity grid. In rural areas, access or use of electricity does not necessarily improve incomeearning options or household income, but complements the household energy mix and can increase wellbeing in other ways. This study shows clearly that the most critical aspects for a transition towards modern and clean household energy use are access and affordability, especially for the lowest income groups.

Cambodia is undergoing a shift towards a more industrialized and service-oriented economy. In this socio-cultural transition process, people are gradually shifting from agricultural income generation to new means of livelihood. Still, in rural provinces, agriculture continues to play a strong role in livelihoods. This context should be taken into account when assessing the shift towards more sustainable energy production and consumption patterns in the Global South and also in Cambodian rural areas. Urbanization progresses at different rates in different provinces in Cambodia and will affect the functioning and organization of the local energy system. Available energy production and consumption mixes also have impacts on the resilience of local communities. As noted above, unexpected regression in the critical steps of energy ladders is possible, and development is not always linear and progressive. We underline that the Integrated Community Energy Systems approach, ICES, could have desirable outcomes in Cambodian rural areas such as (1) collective economic returns, (2) reduced fuel poverty, (3) carbon mitigation, (4) greater community cohesion, and (5) an increased knowledge of sustainable energy technologies.

To facilitate a successful sustainable energy transition, relevant policies play an important role in guiding frameworks and leveling the playing field for safe, reliable, affordable and accessible modern energy. Policy implications of the results of this study combined with analysis of the most recent literature suggest:

First a careful analysis and determination of reasons behind energy poverty and corresponding policy actions and incentive/subsidy mechanisms to bring modern energy services to all. This work has already started with Phoumin \& Kimura, 2019 and Phoumin et al. 2020, but compliling data should be continued with right solutions to multi-faceted drivers of energy poverty. Here the solutions should be tailored to on-grid and off-grid areas, and with different approaches to rural and urban energy consumers.

Second, clear renewable energy targets and strategies that acknowledge first and foremost the needs of energy poor households. This process is underway to a certain extent (ADB 2018), with some targets potentially ready by 2023.

Third, the enabling environment (with standards, rules and regulations e.g. feed-in to the grid) and incentives (tariff subsidies, loans and financing) to increase competitiveness for renewable energy investments at different levels and locations (from households to production, REEs to investors). This work has been initiated with various international and national organisations working on energy in Cambodia, but lack clear guidance, code of conduct and policy frameworks from the regulators, licensees and Royal Government of Cambodia.

Fourth, targeted measures to improve and increase the grid infrastructure both in national and rural isolated grids to prevent damage to devices, shortages, and blackouts for better performance, voltage control and reliability. There are actions underway in process, e.g. by ADB.

Fifth, improving the quality standards and affordability and ownership of modern energy equipment (e.g. solar home systems). This has been noted by many, e.g. ADB (2018) and World Bank (2018)

Finally, realistic future projections of energy use where supply and demand measures are pursued in parallel. Here the recent studies by Konrad Adenauer Stiftung (KAS) and 
Economic Research Institute of ASEAN and East-Asia (ERIA) can provide the baseline for further studies. Especially multi-sector stakeholder workshops could be beneficial here to find synergies from other programming on, for example, green growth strategies, climate change, and national Sustainable Development Goals efforts. All of the above policy recommendations provide ample space for future research for a transition towards sustainable energy futures for all in Cambodia.

Acknowledgements The authors wish to thank the Academy of Finland for funding the GET-LDC project (Green Economy Transitions in the Least Developed Countries); a multi-scale analysis of energy and forest use in Laos and Cambodia (research project number 277182). We are grateful to the directors and staff of our partner institution at the Department of Environmental Science, Royal University of Phnom Penh, for their instrumental support and data collection. Finally we would like to acknowledge and thank the 78 village leaders and 970 households for sharing their knowledge and time.

Funding Open access funding provided by University of Turku (UTU) including Turku University Central Hospital.

\section{Declarations}

Conflict of interest The authors declare that there is no conflict of interest.

Open Access This article is licensed under a Creative Commons Attribution 4.0 International License, which permits use, sharing, adaptation, distribution and reproduction in any medium or format, as long as you give appropriate credit to the original author(s) and the source, provide a link to the Creative Commons licence, and indicate if changes were made. The images or other third party material in this article are included in the article's Creative Commons licence, unless indicated otherwise in a credit line to the material. If material is not included in the article's Creative Commons licence and your intended use is not permitted by statutory regulation or exceeds the permitted use, you will need to obtain permission directly from the copyright holder. To view a copy of this licence, visit http://creativecommons.org/licenses/by/4.0/.

\section{References}

Adamu, M. B., Adamu, H., Ade, S. M., \& Akeh, G. I. (2020). Household energy consumption in Nigeria: A review on the applicability of the energy ladder model. Journal of Applied Sciences and Environmental Management, 24(2), 237

Aldieri, L., Makkonen, T., \& Vinci, C. P. (2020). Environmental knowledge spillovers and productivity: A patent analysis for large international firms in the energy, water and land resources fields. Resources Policy. https://doi.org/10.1016/j.resourpol.2020.101877.AccessedFebruary

Asian Development Bank (2018). Energy Sector Assessment, Strategy and Roadmap. Retrieved Feb 2021 from, https://www.adb.org/sites/default/files/institutional-document/479941/cambodia-energy-asses sment-road-map.pdf

Bhattacharyya, S. C. (2012). Energy access programmes and sustainable development: A critical review and analysis. Energy for Sustainable Development, 16, 260-271. https://doi.org/10.1016/j.esd.2012.05.002

Daioglou, V., Van Ruijven, B. J., \& Van Vuuren, D. P. (2012). Model projections for household energy use in developing countries. Energy, 37(1), 601-615. https://doi.org/10.1016/j.energy.2011.10.044

Davis, M. (1998). Rural household energy consumption: The effects of access to electricity-evidence from South Africa. Energy Policy, 26(3), 207-217. https://doi.org/10.1016/S0301-4215(97)00100-6

Department of Rural Electrification Fund. (2016). Report on Activities of the Department of Rural Electrification Fund for the Year 2015. Retrieved June 292018 from, http://ref.gov.kh/page/admin/public/asset/ article-asset/REF\%20report\%202015_Eg.pdf

Ferranti, R., Fullbrook, D., McGinley, J. and Higgins, S. (2016). Switching On: Cambodia's Path to Sustainable Energy Security. Mekong Strategic Partners. January 2016, Phnom Penh. Retrieved March 20 2019 from, https://mekongcitizen.org/wp-content/uploads/2015/11/Switching-On-Cambodias-Path-toSustainable-Energy-Security.pdf 
Ehara, M., Hyakumura, K., Nomura, H., Maatsura, T., Sokh, H., \& Lng, C. (2016). Identifying characteristics of households affected by deforestation in their firewood and non-timber forest product collections: Case study in Kampong Thom Province, Cambodia. Land Use Policy, 52, 92-102

Ekholm, T., Krey, V., Pachauri, S., \& Riahi, K. (2010). Determinants of household energy consumption in India. Energy Policy, 38, 5696-5707. https://doi.org/10.1016/j.enpol.2010.05.017.Accessed20April 2019

Elias R.J. and Victor D.G. (2005). Energy transitions in developing countries: a review of concepts and literature. Program on energy and sustainable development. Stanford University. Retrieved March 20 2019 from, https://unity.org/files/158401_158500/158492/elias-and-victor-2005.pdf

Energypedia (2021). Cambodia Energy Situation. Retrieved Feb 92021 from, https://energypedia.info/wiki/ Cambodia_Energy_Situation

ERIA. (2016). Cambodia National Energy Statistics 2016. Ministry of Mines and Energy of Cambodia. Retrieved June 202018 from, http://www.eria.org/RPR_FY2015_08.pdf

ESMAP. (1999). Household Energy Strategies for Urban India: The Case of Hyderabad. Joint UNDP/ World Bank Energy Sector Management Assistance Programme (ESMAP), Washington, DC. Retrieved Apr 202019 from, https://www.esmap.org/sites/default/files/esmap-files/Rpt_India_ hyderabadesm214.pdf

ESMAP. (2003). Household Energy Use in Developing Countries: A Multicountry Study. Joint UNDP/ World Bank Energy Sector Management Assistance Programme (ESMAP), Washington, DC. Retrieved April 202019 from, http://hdl.handle.net/10986/19647

Giotitsas, C., Pazaitis, A., \& Kostakis, P. (2015). A peer-to-peer approach to energy production. Technology and Society, 42, 28-38. https://doi.org/10.1016/j.techsoc.2015.02.002.Accessed20January2019

Hansen, M.C., Potapov, P.V., Moore, R., Hancher, M., Turubanova, S. A., Tyukavina, A.D., Stehman, S. V., Goetz, S. J., Loveland, T. R., Kommareddy, A., Egorov, A., Chini, L., Justice, C. O., and Townshend, J. R. G. (2013). High-Resolution Global Maps of 21st-Century Forest Cover Change. Science 342 (15 November): 850-53. Data available online from: Retrieved March 20, 2019 from, http://earthenginepartners.appspot.com/science-2013-global-forest

Heltberg, R. (2004). Fuel switching evidence from eight developing countries. Energy Economics, 26, 869-887. https://doi.org/10.1016/j.eneco.2004.04.018

Heltberg, R. (2005). Factors determining household fuel choice in Guatemala. Environment and Development Economics, 10, 337-361. https://doi.org/10.1017/S1355770X04001858

Heng, P, Boyle, M. (2020). Cambodia 2040- Chapter 7. Energy. Konrad Adenauer Stiftung . Retrieved Feb 82021 from, https://www.kas.de/en/web/kambodscha/single-title/-/content/energy-1

Hosier, R. H., \& Dowd, J. (1987). Household fuel choice in Zimbabwe: An empirical test of the energy ladder hypothesis. Resources and Energy, 9(4), 347-361. https://doi.org/10.1016/0165-0572(87)90003-X

IEA. (2019). SDG7: Data and Projections- Access to affordable, reliable, sustainable and modern energy for all. Retrieved Feb 92021 from, https://www.iea.org/reports/sdg7-data-and-projections/accessto-electricity

IEA. (2015). World Energy Outlook 2015. Executive summary. OECD/IEA. Retrieved Oct 202018 from, https://webstore.iea.org/download/summary/224?fileName=English-WEO-2015-ES.pdf

IEA. (2017). Energy Access Outlook 2017. From Poverty to Prosperity. World Energy Outlook Special Report: 39 Retrieved March 202019 from, https://www.iea.org/publications/freepublications/publi cation/WEO2017SpecialReport_EnergyAccessOutlook.pdf

IEA (2018). CO2 emissions from fuel combustion 2018 overview. Retrieved March 202019 from, https://www.iea.org/statistics/co2emissions/

Jagadish, A., \& Dwivedi, P. (2018). In the hearth, on the mind: Cultural consensus on firewood and cookstoves in the middle Himalayas of India. Energy Research and Social Science, 37, 44-51. https://doi.org/10.1016/j.erss.2017.09.017

Kallio, M., Monge Monge, A., Kanninen, M., Hogarth, N.J., Korkeakoski, M., Vähäkari, N., Chea, E. and Va, D 2019 (submitted). Life under multiple stressors: household perceptions of change in Cambodia. (Forthcoming)

Kimura, S., Phoumin, H. (2019). Energy Outlook and Energy Saving Potential in East Asia 2019. Economic Research Institute for ASEAN and East Asia. Retrieved Feb 92021 from, http://hdl.handle. net/11540/9786

Koirala, B. P., Koliou, E., Friege, J., Hakyoort, R. A., \& Herder, P. M. (2016). Energetic communities for community energy: Are view of key issues and trends shaping integrated community energy systems. Renewable and Sustainable Energy Reviews, 56(722-744), 2019. https://doi.org/10.1016/j. rser.2015.11.080.Accessed20March 
Kowsari, R., \& Zerriffi, H. (2011). Three dimensional energy profile: A conceptual framework for assessing household energy use. Energy Policy, 39(7505-7517), 2019. https://doi.org/10.1016/j. enpol.2011.06.030.Accessed20March

Kroon, V. B., Brouwer, R., \& Beukering, P. (2013). The energy ladder: Theoretical myth or empirical truth? Results from a meta-analysis. Renewable and Sustainable Energy Reviews, 20(504-513), 2019. https://doi.org/10.1016/j.rser.2012.11.045.Accessed20March

Lao, P. A., Lamberet, B., \& Ramage, I. (2013). Nationwide Domestic Use of Cooking Fuels and Devices: Baseline Survey: 10. Geres Cambodia. Angkor Research and Consulting Ltd.

Leach, G. (1992). The energy transition. Energy Policy, 20(2), 116-123. https://doi.org/10.1016/03014215(92)90105-B

Luukkanen, J. (1991). Energy Use in Rural Tanzania, Energy and Development Report 16, Tampere University of Technology.

Masera, O. R., Saatkamp, B. D., \& Kammen, D. M. (2000). From linear fuel switching to multiple cooking strategies: A critique and alternative to the energy ladder model. World Development, 28(12), 2083-2103. https://doi.org/10.1016/S0305-750X(00)00076-0

Mendes, G., Loakimidis, C., \& Ferraro, P. (2011). On the planning and analysis of integrated community energy systems: Are view and survey of available tools. Renewable and Sustainable Energy Review, 15, 4836-4854. https://doi.org/10.1016/j.rser.2011.07.067

Ministry of Mines and Energy of Cambodia (2020). Energy Efficiency and Conservation Master Plan of Cambodia. Economic Research Institute for ASEAN and East Asia (ERIA). Retrieved Feb 9 2021 from, https://think-asia.org/bitstream/handle/11540/12326/Energy-Efficiency-and-Conservati on-Master-Plan-of-Cambodia.pdf?sequence $=1$

Ministry of Planning, National Institute of Statistics (2017). Population Projection of Cambodia 20132023. Based on Cambodia Inter-Censal Population Survey 2013 and Cambodia Demographic and Health Survey 2014. Retrieved Sep 152018 from, https://www.stat.go.jp/info/meetings/cambodia/ pdf/ci_fn02.pdf

Ministry of Environment (2013). National Strategic Plan on Green Growth 2013-2030. Royal Government of Cambodia. Retrieved Dec 122019 from, http://www.greengrowthknowledge.org/sites/ default/files/downloads/policy-database/CAMBODIA $\% 29 \% 20$ National $\% 20$ Strategic $\% 20 \mathrm{Plan} \%$ 20on\%20Green\%20Growth\%202013-2030.pdf

Nguyen, T., Do, T., Bühler, D., Hartje, R., \& Grote, U. (2015). Rural livelihoods and environmental resource dependence in Cambodia. Ecological Economics, 120(282-295), 2018. https://doi.org/10. 1016/j.ecolecon.2015.11.001.Accessed15September

NIS (National Institute of Statistics), Ministry of Planning. (2008). General Population Census of Cambodia 2008 - Provisional population totals. PDF loaded 7.11.2017 from Retrieved March 20, 2019 from, http://www.stat.go.jp/english/info/meetings/cambodia/pdf/pre_rep1.pdf

Pachauri, S. (2004). An analysis of cross-sectional variations in total household energy requirements in India using micro survey data. Energy Policy, 32, 1723-1735. https://doi.org/10.1016/S03014215(03)00162-9.Accessed15.September2018

Phoumin, H., \& Kimura, F. (2019). Cambodia's energy poverty and its effect on social wellbeing: Empirical evidence and policy implications. Energy Policy, 132, 283-289

Phoumin, H., Kimura, F., \& Sandu, S. (2020). Household-level analysis of the impacts of electricity consumption on welfare and the environment in Cambodia: Empirical evidence and policy implications. Economic Modelling, 89, 476-483. https://doi.org/10.1016/j.enpol.2019.05.032

Poch, K. (2013). Renewable energy development in Cambodia: Status, prospects and policies. In Kimura, S., Phoumin H., Jacobs B. (Eds.), Energy Market Integration in East Asia: Renewable Energy and Its Deployment into the Power System (pp. 227-266). Economic Research Institute for ASEAN and East Asia. https://www.researchgate.net/publication/285981833_Renewable_energy_development_ in_Cambodia_Status_prospects_and_policies/link/5747b0ea08ae707fe21e419c/download.

Probability proportional to size (PPS) sampling. Wiley StatsRef: Statistics Reference Online, 2014 Wiley Online Library. https://doi.org/https://doi.org/10.1002/9781118445112.stat03346.pub2. Accessed 9 February 2021. https://openknowledge.worldbank.org/bitstream/handle/10986/29512/ 124490.pdf?sequence=5\&isAllowed=y Accessed 9 February 2021

Royal Government of Cambodia (2015). Poverty Rates by Communes, Sangkats, Districts, Khans, Provinces, and Municipalities, Based on Commune Database 2014. Phnom Penh, Ministry of Planning: 66 in Khmer language.

Räsänen, T. A., Varis, O., Scherer, L., \& Kummu, M. (2018). Greenhouse gas emissions of hydropower in the Mekong River Basin. Environmental Research Letters, 13, 2018. https://doi.org/10.1088/ 1748-9326/aaa817.Accessed15September 
San, V., Sriv, T., Spoann, V., Var, S., \& Seak, S. (2012). Economic and environmental costs of rural household energy consumption structures in Sameakki Meanchey district, Kampong Chhnang Province. Cambodia. Energy, 48(1), 484-491

San, V., Spoann, V., Ly, D., \& Chheng, N. V. (2012). Fuelwood consumption patterns in Chumriey mountain, Kampong Chhnang province. Cambodia. Energy, 44(1), 335-346

SCW (Atlas Committee). (2006). The School Atlas of Cambodia. Save Cambodia's Wildlife.

Schweizer-Ries, P. (2008). Energy sustainable communities: Environmental psychological investigations. Energy Policy, 4126-4135, 2018. https://doi.org/10.1016/j.enpol.2008.06.021.Accessed15. September

Siciliano, G., Urban, F., Kim, S., \& Lonn, P. D. (2015). Hydropower, social priorities and the ruralurban development divide: The case of large dams in Cambodia. Energy Policy, 86, 273-285. https://doi.org/10.1016/j.enpol.2015.07.009

United Nations (2015). Transforming our world: the 2030 Agenda for Sustainable Development. Retrieved Feb 9, 2021 from, https://sdgs.un.org/2030agenda

UNDP (2016). Human Development Report 2016. Human Development for Everyone. Briefing note for countries on the 2016 Human Development Report. PDF downloaded 25.5.2018 from Retrieved Mar 202019 from, http://hdr.undp.org/sites/all/themes/hdr_theme/country-notes/KHM.pdf

United Nations Department of Economic and Social Affairs, Population Division (2015). World Population Prospects: The 2015 Revision, Key Findings and Advance Tables. Working Paper No. ESA/P/WP.241. Retrieved Sep 15, 2018 from, https://esa.un.org/unpd/wpp/publications/files/key_findings_wpp_2015. pdf

United Nations, Economic and Policy Division, Least Developed Country Category. (2018). Cambodia. Triennial Review 2018. From: Retrieved Sep 152018 from,https://www.un.org/development/desa/dpad/ least-developed-country-category-cambodia.html

UNEP (2011) Towards a Green Economy: Pathways to Sustainable Development and Poverty Eradication. 100 Watt, St-Martin-Bellevue, France. Retrieved Sep 15, 2018 from, www.globalurban.org/UNEP_ Green_Economy_Report--Synthesis.pdf

Victor, D. G. (2002). A Vision for Global Electrification. The Program on Energy and Sustainable Development (PESD), Stanford University, Stanford. Retrieved Sep 15, 2018 from, https://fsi-live.s3.us-west-1. amazonaws.com/s3fs-public/energy_transitions.pdf

Walker, G., \& Simcock, N. (2012). Community energy systems. International Encyclopedia of Housing and Home, 1(194-198), 2019. https://doi.org/10.1016/B978-0-08-047163-1.00598-1.Accessed10May

Wickramasinghe, A. (2011). Energy access and transition to cleaner cooking fuels and technologies in Sri Lanka: Issues and policy limitations. Energy Policy, 39, 7567-7574. https://doi.org/10.1016/j.enpol. 2011.07.032

World Bank Data Base (2017). Cambodia 1990-2016 Retrieved Mar 20, 2019 from, https://data.worldbank. org/indicator/EG.ELC.ACCS.ZS?end=2016\&locations $=$ KH\&start=1990\&view $=$ chart

World Bank Data Base (2021). Cambodia 1998-2018 - Access to electricity(\%) - Total, Urban, Rural and Percentage of Rural population 1970-2019. Retrieved Feb 9, 2021 from, https://data.worldbank.org/ indicator/EG.ELC.ACCS.ZS?end=2016\&locations $=$ KH\&start $=1990 \&$ view $=$ chart

World Bank (2018). CAMBODIA Beyond Connections - Energy Access Diagnostic Report Based on the Multi-Tier Framework.

Vuola, M., Korkeakoski, M., Vähäkari, N., Dwyer, M. B., Hogarth, N. J., Kaivo-oja, J., Luukkanen, J., Chea, E., Thuon, T., \& Phonhalath, K. (2020). What is a green economy? Review of national-level green economy policies in Cambodia and Lao PDR. Sustainability., 12(16), 6664. https://doi.org/10. $3390 /$ su12166664

WWF. (2016). Power Sector Vision. Towards 100\% Renewable Electricity by 2050. Greater Mekong Region, Cambodia Report. Retrieved Mar 20, 2019 from, http://d2ouvy59p0dg6k.cloudfront.net/downl oads/cambodia_power_sector_scenarios_final.pdf

Publisher's Note Springer Nature remains neutral with regard to jurisdictional claims in published maps and institutional affiliations. 